\title{
Evaluation, Satisfaction, and Loyalty in the Context of Green Credit Card Services: Green Ethics as a Moderator
}

\author{
Moon-YongKim*1 \\ ${ }^{*}$ College of Business, Hankuk Univ. of Foreign Studies, SEOUL, Republic ofKorea moonyong@ hufs.ac.kr ${ }^{1}$
}

Article History: Received: 11 January 2021; Accepted: 27 February 2021; Published online: 5 April 2021

\begin{abstract}
This research aims to examine the relationships among evaluation of green credit card services, overall satisfaction with green credit card services, and loyalty to green credit cards.In addition, this search examines whether consumers' green ethics moderates the relationship between evaluation of green credit card services and loyalty to green credit cards. An online survey $(\mathrm{N}=2,000)$ was conducted to test the hypotheses. Consistent with all the hypotheses, the results indicate that (1) evaluation of green credit card services has a positive effect on overall satisfaction with green credit card services (hypothesis 1); (2) evaluation of green credit card services has a positive effect on loyalty to green credit cards (hypothesis 2); (3) overall satisfaction with green credit card services has a positive effect on loyalty to green credit cards (hypothesis 3); (4) overall satisfaction with green credit card services mediates the relationship between evaluation of green credit card services and loyalty to green credit cards (hypothesis 4); and (5) the magnitude of the positive effect of evaluation of green credit card services on loyalty to green credit cards increases as individuals' green ethics decreases (hypothesis 5).
\end{abstract}

Keywords: Green credit card, green ethics, evaluation, satisfaction, loyalty.

\section{Introduction}

Credit cards have always been regarded as an essential substitute for cash that could lead to a cashless society in the future [1]. Greater convenience and social acceptability as well as easy access may stimulate consumer spending further through increased demand for credit cards. In addition, credit and debit cards replace cash as the preferred mode of payment because they are relatively painless forms of payment [2]. Previous research has discovered that the credit card, a significant factor to spending-facilitating stimuli, may elevate compulsive buying [3, 4]. In recent years, increasing attention is evident with regard to the depletion of natural resources, the development of "green" products and services and the sustainability practices of organizations [5]. For example, eco-friendly automobiles such as low-noise, low-pollution, and high-efficiency automobiles have emerged [6]. In particular, green credit cards are the card services to revitalize the eco-friendly life of the people, offering a variety of benefits to card users for supporting environment[7]. For instance, green credit cards help card users deposit the points by calculating the distance in which they travel on foot or by bicycle.

Therefore, this research aims to examine the relationships among evaluation of green credit card services, overall satisfaction with green credit card services, and loyalty to green credit cards. In addition, this research examines whether consumers' green ethics moderates the relationship between evaluation of green credit card services and loyalty to green credit cards. Specifically, in the current research, it is predicted (1) evaluation of green credit card services will have a positive effect on overall satisfaction with green credit card services (hypothesis 1); (2) evaluation of green credit card services will have a positive effect on loyalty to green credit cards (hypothesis 2); (3) overall satisfaction with green credit card services will have a positive effect on loyalty to green credit cards (hypothesis 3); (4) overall satisfaction with green credit card services will mediate the relationship between evaluation of green credit card services and loyalty to green credit cards (hypothesis 4); and (5) the magnitude of the positive effect of evaluation of green credit card services on loyalty to green credit cards will increase as individuals' green ethics decreases (hypothesis 5).

\section{Theoretical Background and Hypothesis Development}

A number of studies have reported that quality evaluation and customer satisfaction are strongly related [810].Previous studies indicated that perceived evaluation of customers demonstrated a strong and positive impact upon their repurchase intentions [11]. Tam [12] argued that perceived evaluation of customers would positively influence their postpurchasebehaviors. In addition, perceived evaluation of customers is a primary factor influencing their purchase intentions and loyalty [13].

In addition, customer satisfaction has an important role as the antecedent of customer loyalty [14]. Oliver [14] suggested that customers first become loyal in the cognitive sense, then later in affective sense, and still later in a conative or behavioral manner. The outcome of satisfaction is loyalty, and in turn satisfaction has a positive impact on loyalty [15-17].

Furthermore, the loyalty of customers with higher green ethics may be less influenced by the general benefits of credit card services when compared to those with lower green ethics. That is, general benefits of credit card 
services are considered critical for inducing benefit evaluation, satisfaction, and behavioral intentions (loyalty) in customers who have lower green ethics.

Thus, this research proposes the following hypotheses:

H1: Evaluation of green credit card services has a positive effect on overall satisfaction with green credit card services.

H2: Evaluation of green credit card services has a positive effect on loyalty to green credit cards.

H3: Overall satisfaction with green credit card services has a positive effect on loyalty to green credit cards.

H4: Overall satisfaction with green credit card servicesMediates the relationship between evaluation of green credit card services and loyalty to green credit cards.

H5: The magnitude of the positive effect of evaluation of green credit card services on loyalty to green credit cards increases as consumers' green ethics decreases.

\section{Method and Results}

A total of 2,000 green credit/debit card users completed the online survey. About $54.7 \%$ of the respondents were male. The average age was 34.68 years. The percentage of all respondents was $19.9 \%$ at ages $20-29,33.7 \%$ at ages $30-39,27.0 \%$ at ages $40-49$, and $19.5 \%$ at ages $50-59$.

\subsection{Measure}

This study used seven-point Likert scale from 1 to 7 rating from strong disagreement to strong agreement to measure the questionnaire items. Specifically, this study referred to Chen [18] to measure evaluation of green credit card services. The measurement of evaluation includes three items. Overall satisfaction with green credit card services was measured using a single item. In previous research, for doubly concrete constructs, single-item measures demonstrated predictive validity equal to that of multiple-item measures [19-25]. Moreover, researchers may decide to opt for single-item measures in light of their manifold practical advantages [26-28]. This study referred to Oliver [14] to measure loyalty to green credit cards. The measurement of loyalty includes three items. This study referred to Olson [29] to measure consumers' green ethics. The measurement of green ethics includes three items.

\subsection{Measurement Validation}

Prior to testing hypotheses, this research examined reliabilities and validities of measurement items used for the three constructs that were measured by the respondents' evaluation (i.e.,evaluation, loyalty, and green ethics). A confirmatory factor analysis (CFA) was conducted by using AMOS 20 for the three constructs (Table 1). The goodness-of-fit statistics indicated an adequate fit of the measurement model $\left(\chi^{2} /\right.$ d.f. $=357.907 / 30=11.930(\mathrm{p}=$ $.000) ; \mathrm{RMR}=.040 ; \mathrm{GFI}=.964 ; \mathrm{NFI}=.980 ; \mathrm{IFI}=.981 ; \mathrm{TLI}=.972 ; \mathrm{CFI}=.981 ; \mathrm{RMSEA}=.074)$. Reliabilities were assessed by internal consistency (Cronbach's alpha $>0.7$ ) as well as composite reliability (CR) measures. The Cronbach's alphas and the CRs exceeded a cut-off value of 0.7 for the three constructs, supporting the reliability of the measurement items used for each construct [30].

Convergent validities were assessed by standardized loading estimates, squared multiple correlation (SMC), and average variance extracted (AVE) [30, 31]. Running a confirmatory factor analysis with a single indicator for overall satisfaction integrated as recommended by Anderson and Gerbing[32] reveals that the standardized factor loadings for all constructs exceeded the threshold of 0.5; SMCs were greater than 0.5; and AVEs exceeded 0.5 , supporting the convergent validity for each construct (see Table 1). The square root of AVE for each construct was greater than the correlations between the construct and other constructs included in the model (see Table 2), verifying the discriminant validity of the three constructs [31]. In addition, nomological validity was assessed based on the correlation matrix of the three constructs [30]. The results showed that these constructs were positively related to one another, corresponding to the discussions this study presented earlier.

\begin{tabular}{|c|c|c|c|c|c|}
\hline Construct & $\begin{array}{c}\text { Measurement } \\
\text { items }\end{array}$ & $\begin{array}{l}\text { Standardized } \\
\text { factor loading }\end{array}$ & CR & SMC & AVE \\
\hline Evaluation & V1 & .862 & .910 & .743 & .771 \\
\hline \multirow[t]{2}{*}{ (Cronbach's $\alpha=.934$ ) } & $\mathrm{V} 2$ & .951 & & .905 & \\
\hline & V3 & .916 & & .840 & \\
\hline Loyalty & V4 & .918 & .877 & .843 & .704 \\
\hline \multirow[t]{2}{*}{ (Cronbach's $\alpha=.913$ ) } & v5 & .862 & & .744 & \\
\hline & V6 & .875 & & .766 & \\
\hline Green ethics & V7 & .847 & .875 & .718 & .701 \\
\hline \multirow[t]{2}{*}{ (Cronbach's $\alpha=.895$ ) } & V8 & .946 & & .896 & \\
\hline & V9 & .794 & & .631 & \\
\hline
\end{tabular}

Table 2. Means, Standard Deviations, Correlations among Constructs, and the Square Root of AVE for Each Construct 


\begin{tabular}{|c|c|c|c|c|c|c|}
\hline Construct & Mean & $\begin{array}{l}\text { Standard } \\
\text { deviation }\end{array}$ & 1 & 2 & 3 & 4 \\
\hline $\begin{array}{ll}\text { 1. } & \begin{array}{l}\text { Benefit } \\
\text { evaluation }\end{array}\end{array}$ & 5.04 & 1.13 & .878 & & & \\
\hline $\begin{array}{ll}\text { 2. Overall } \\
\text { satisfaction }\end{array}$ & 5.10 & 1.21 & $.769^{* *}$ & - & & \\
\hline 3. Loyalty & 5.26 & 1.13 & $.773^{* *}$ & $.673^{*}$ & .839 & \\
\hline 4. Green ethics & 5.24 & 1.03 & $.371^{* *}$ & $.270^{* *}$ & $.399^{* *}$ & .838 \\
\hline
\end{tabular}

\subsection{Hypothesis Testing}

To analyse the structural model, this study employs maximum likelihood estimation, run in AMOS 20. Marsh, Wen, and Hau[33] suggest estimating an overall model in which the interaction effects are integrated based on the unconstrained approach. Running this model shows adequate overall fit fulfilling the usual fit criteria recommended in literature $\chi^{2} /$ d.f. $=508.258 / 58=8.763(\mathrm{p}=.000) ; \mathrm{RMR}=.048 ; \mathrm{GFI}=.961 ; \mathrm{NFI}=.976$; $\mathrm{IFI}=.978 ; \mathrm{TLI}=.971 ; \mathrm{CFI}=.978 ; \mathrm{RMSEA}=.062[34]$. Table3 illustrates the results of the model testing and reports standardized path coefficientsestimated by the structural model as well as the bootstrapping biascorrected 95\% confidence interval (CI). The standardized path coefficients for evaluation of green credit card services ( $\beta=.884,95 \%$ CI from .858 to $.908, p=.000$ ) on overall satisfaction with green credit card services is significant and positive. Overall satisfaction with green credit card services yields a significant impact on loyalty to green credit cards $(B=.268,95 \% \mathrm{CI}$ from .154 to $.387, \mathrm{p}=.000)$. In addition, evaluation of green credit card services exerts a significant and positive direct effect on loyalty to green credit cards $(\beta=.541,95 \%$ CI from .424 to $.651, \mathrm{p}=.000$ ), therefore, the findings support $\mathrm{H} 1, \mathrm{H} 2$, and $\mathrm{H} 3$.

As Zhao, Lynch, and Chen [35] recommend, the study employs the bias-corrected bootstrapping procedure in AMOS to test whether overall satisfaction with green credit card services acts as a mediator between the evaluation of green credit card services and loyalty to green credit cards. Drawing 5,000 bootstrap samples with a 95\% bias-corrected confidence, the results suggest that the standardized indirect effects of evaluation of green credit card services $(\beta=.237$; bias-corrected $95 \% \mathrm{CI}$ : lower level $=.137$, upper level $=.346, \mathrm{p}=.000)$ on loyalty to green credit cards is positive and significant, with a 95\% confidence interval excluding zero [36]. The fact that a significant direct effect exists forevaluation of green credit card services on loyalty to green credit cards indicates that overall satisfaction with green credit card services partially mediates the effect of evaluation of green credit card services on loyalty to green credit cards, which provides support for the mediation hypothesis $\mathrm{H} 4$.

Assessing whether green ethics moderates the relationship between evaluation of green credit card services and loyalty to green credit cards requires computing the relevant latent interaction terms. This is done by meancentering all construct indicator variables and the moderating variable, and then multiplying each indicator variable by the single indicator of the moderating variable. Integrating the resulting interaction term into the structural model reveals an interaction effect to be significant. That is, the interaction effect between evaluation of green credit card services and green ethics on loyalty to green credit cards $(\beta=-.044, p=.004)$ is negative (see Table 3). This result indicates that the effect of evaluation of green credit card services on loyalty to green credit cards becomes stronger for consumers with lower green ethics. As such, the finding supports the moderation hypothesis $\mathrm{H} 5$.

Table 3.Statistical Results of Structural Model

\begin{tabular}{|c|c|c|c|c|c|}
\hline \multirow{2}{*}{ Path } & \multirow{2}{*}{$\beta$} & \multirow{2}{*}{ SE } & \multirow{2}{*}{ CR } & \multicolumn{2}{|c|}{ Bias-Corrected Bootstrap 95\% CI } \\
\hline & & & & Lower & Upper \\
\hline $\begin{array}{l}\text { Evaluation } \\
\rightarrow \text { Overall satisfaction }\end{array}$ & $.884^{* * *}$ & .020 & 44.638 & .858 & .908 \\
\hline $\begin{array}{l}\text { Evaluation } \\
\rightarrow \text { Loyalty }\end{array}$ & $.541^{\cdots *}$ & .048 & 11.559 & .424 & .651 \\
\hline $\begin{array}{l}\text { Overall satisfaction } \\
\rightarrow \text { Loyalty }\end{array}$ & $.268^{* * *}$ & .048 & 5.631 & .154 & .387 \\
\hline $\begin{array}{l}\text { Green ethics } \\
\rightarrow \text { Loyalty }\end{array}$ & $.120^{\cdots}$ & .018 & 7.269 & .080 & .161 \\
\hline $\begin{array}{l}\text { Evaluation } \\
\mathrm{x} \text { Green ethics } \\
\rightarrow \text { Loyalty }\end{array}$ & $-.044^{* *}$ & .012 & -2.916 & -.082 & -.005 \\
\hline
\end{tabular}

\section{Conclusions}

The present research investigates the relationships among evaluation of green credit card services, overall satisfaction with green credit card services, and loyalty to green credit cards. In addition, this research examines 
whether consumers' green ethics moderates the relationship between evaluation of green credit card services and loyalty to green credit cards.

In support of all the hypotheses, the results indicate that (1) evaluation of green credit card services has a positive effect on overall satisfaction with green credit card services (hypothesis 1); (2) evaluation of green credit card services has a positive effect on loyalty to green credit cards (hypothesis 2); (3) overall satisfaction with green credit card services has a positive effect on loyalty to green credit cards (hypothesis 3); (4) overall satisfaction with green credit card services mediates the relationship between evaluation of green credit card services and loyalty to green credit cards (hypothesis 4); and (5) the magnitude of the positive effect of evaluation of green credit card services on loyalty to green credit cards increases as individuals' green ethics decreases (hypothesis 5).

This study seeks to provide an evaluation of new concepts of green marketing in the context of green credit card services and increase consumers' loyalty to green credit cards from three drivers: evaluation, overall satisfaction and green ethics.

Although this research provides theoretical and practical implications, it is not without limitations. First, it would be good for future research to examine if the findings are applicable to other financial products/services or payment mode. Finally, future research should consider other potential factors that can influence card users' overall satisfaction and loyalty.

\section{Acknowledgment}

This research was supported by Hankuk University of Foreign Studies Research Fund of 2020.

\section{References}

1. Levy, M., \&Ingene, C. A. (1983). Retailers: Head Off Credit Cards with Cash Discounts? Harvard Business Review, 61(3), 18-21.

2. Prelec, D., \& Loewenstein, G. (1998). The Red and the Black: Mental Accounting of Savings and Debt. Marketing Science, 17(1), 4-28.

3. O'Guinn, T. C., \& Faber, R. J. (1989). Compulsive Buying: A Phenomenological Exploration. Journal of Consumer Research, 16(2), 147-157.

4. Roberts, J. A., \& Jones, E. (2005). Money Attitudes, Credit Card Use, and Compulsive Buying among American College Students. Journal of Consumer Affairs, 35(2), 213-240.

5. Bullard, O., \& Manchanda, R. V. (2013). Do Sustainable Products Make Us Prevention Focused? Marketing Letters, 24(2), 177-189.

6. Lee, S., Park, H., \& Bae, M.-J. (2017). A Study on the Design of Virtual Engine Sound of EcoFriendly Vehicle. International Journal of Internet, Broadcasting and Communication, 9(2), 37-41.

7. Kim, M.-Y. (2020). Ethical Behavior in the Context of Green Credit Card Services: The Role of Individuals' Regulatory Focus. International Journal of Advanced Culture Technology, 8(1), 107112.

8. Caruana, A. (2002). Service Quality: The Effects of Service Quality and the Mediating Role of Customer Satisfaction. European Journal of Marketing, 36(7/8), 811-828.

9. Spreng, R. A., \&Chiou, J. (2002). A Cross-Cultural Assessment of the Satisfaction Formation Process. European Journal of Marketing, 36(7/8), 1-8.

10. Zhu, Z.-Y., \& Kim, H.-C. (2020). Antecedents and Consequences of Flow Experience in Online Movie Information Sharing Behavior: An Empirical Study of Young Chinese Moviegoers Living in Korea. International Journal of Advances Smart Convergence, 9(1), 141-153.

11. Patterson, P., \&Spreng, R. (1997). Modeling the Relationship between Perceived Value, Satisfaction and Repurchase Intention in a Business-to-Business Service Context: An Empirical Examination. International Journal of Service Industry Management, 8(5), 414-434.

12. Tam, J. L. M. (2004). Customer Satisfaction, Service Quality and Perceived Value: An Integrative Model. Journal of Marketing Management, 20(7/8), 897-917.

13. Brady, M. K., \& Robertson, C. J. (1999). An Exploratory Study of Service Value in the USA and Ecuador. International Journal of Service Industry Management, 10(5), 469-486.

14. Oliver, R. L. (1999). Whence Consumer Loyalty? Journal of Marketing, 63(4), 33-44.

15. Spiteri, J. M., \& Dion, P. A. (2004). Customer Value, Overall Satisfaction, End-User Loyalty, and Market Performance in Detail Intensive Industries. Industrial Marketing Management,33(8), 675687.

16. Jang, C.-O. (2019). A Study on the Satisfaction of Service Users on Service Sustainability: Focused on Community Service Investment Business. The Journal of the Convergence on Culture Technology, 5(2), 257-261.

17. Lee, S.-B., \& Park, C. (2019). Influence of Characteristics of Performance Video Content on WOM Effect through Trust and Satisfaction. The Journal of the Institute of Internet, Broadcasting and Communication, 19(4), 129-137. 
18. Chen, Y. S. (2013). Towards Green Loyalty: Driving from Green Perceived Value, Green Satisfaction, and Green Trust. Sustainable Development, 21(5), 294-308.

19. Bergkvist,L. (2015).Appropriate Use of Single-Item Measures is Here to Stay. Marketing Letters, 26(3), 245-255.

20. BergkvistL. (2016).The Nature of Doubly Concrete Constructs and How to Identify Them. Journal of Business Research, 69(9), 3427-3429.

21. Bergkvist, L., \&Rossiter, J.R. (2007). The Predictive Validity of Multiple-Item versus Single-Item Measures of the Same Constructs.Journal of Marketing Research, 44(2), 175-184.

22. Bergkvist, L., \&Rossiter, J.R. (2009). Tailor-Made Single-Item Measures of Doubly Concrete Constructs.International Journal of Advertising, 28(4), 607-621.

23. Rossiter, J.R. (2002). The C-OAR-SE Procedure for Scale Development in Marketing.International Journalof Research in Marketing, 19(4), 305-335.

24. Rossiter, J.R. (2011). Marketing Measurement Revolution: The C-OAR-SE Method and Why It MustReplacePsychometrics. European Journal of Marketing, 45(11), 1561-1588.

25. Böckenholt, U., \& Lehmann, D. R. (2015). On the Limits of Research Rigidity: The Number of Items in a Scale.Marketing Letters, 26(3), 257-260.

26. Drolet, A. L., \&Morrison, D. G. (2001). Do We Really Need Multiple-Item Measures in ServiceResearch? Journal of Service Research, 3(3),196-204.

27. Fuchs, C., \&Diamantopoulos, A. (2009). Using Single-Item Measures for Construct Measurement in Management Research. Business Administration Review, 69(2), 195-210.

28. Wanous, J. P., Reichers, A. E., \&Hudy, M. J. (1997). Overall Job Satisfaction: How Good are Single-Item Measures? Journal of Applied Psychology, 82(2), 247-252.

29. Olson, E. L. (2012). It's Not Easy Being Green: the Effects of Attribute Tradeoffs on Green Product Preference and Choice. Journal of Academy of Marketing Science, 41(2), 171-184.

30. Hair, J. F., Black, W. C., Babin, B. J., \& Anderson, R. E. (2010). Multivariate Data Analysis (7th ed.). Prentice Hall: Upper Saddle River.

31. Fornell, C., \&Larcker, D. F. (1981). Evaluating Structural Equation Models with Unobservable Variables and Measurement Error. Journal of Marketing Research, 18(1), 39-50.

32. Anderson, J.C.,\&Gerbing, D.W. (1988). StructuralEquationModeling in Practice: A Review and Recommended Two-Step Approach. Psychological Bulletin, 103(3), 411-423.

33. Marsh, H. W., Wen, Z., \&Hau, K. -T. (2004). Structural Equation Models of Latent Interactions: Evaluation of Alternative Estimation Strategies and Indicator Construction. Psychological Methods, 9(3), 275-300.

34. Hu, L. T., \&Bentler, P. M. (1999). Cutoff Criteria for Fit Indexes in Covariance Structure Analysis: Conventional Criteria versus New Alternatives. Structural Equation Modeling, 6(1), 1-55.

35. Zhao, X., Lynch, G., \&Chen, Q. (2010). Reconsidering Baron and Kenny: Myths and Truths about Mediation Analysis. Journal of Consumer Research, 37(2), 197-206.

36. MacKinnon, D. P., Lockwood, C. M., \& Williams, J. (2004). Confidence Limits for the Indirect Effect: Distribution of the Product and Resampling Methods. Multivariate Behavioral Research, 39(1), 99-128.

37. Mogano, P., \&Mokoele, N. (2019). South African Climate Change Adaptation Politics: Urban Governance Prospects. The International Journal of Social Sciences and Humanity Studies, 11(1), 68-83. 